\title{
Concentrate supplementation during pregnancy and lactation of ewes affects the growth rate of lambs from a variety of crosses
}

\author{
Jacira Neves da Costa Torreão ${ }^{1}$, Arturene Marques Rocha ${ }^{1}$, Carlo Aldrovandi Torreão \\ Marques ${ }^{1}$, Leilson Rocha Bezerra ${ }^{1}$, Fernanda Patrícia Gottardi ${ }^{1}$, Marcos Jácome de Araújo", \\ Edmilson Lúcio de Souza Júnior ${ }^{2}$, Ronaldo Lopes Oliveira ${ }^{3}$
}

\footnotetext{
${ }^{1}$ Departamento de Zootecnia, Universidade Federal do Piauí, Bom Jesus, PI, Brasil.

${ }^{2}$ Departamento de Medicina Veterinária, Universidade Federal de Campina Grande, Patos, PB, Brasil.

${ }^{3}$ Departamento de Zootecnia, Universidade Federal da Bahia, Salvador, BA, Brasil.
}

\begin{abstract}
The objective of this study was to determine how concentrate supplementation during late third gestation and lactation affects ewe and offspring performance from birth to weaning. Thirty-six ewes and their offspring $(\mathrm{n}=32)$ were used. Eighteen Morada Nova and 18 Santa Inês ewes were artificially inseminated with semen from Dorper ram and distributed in a completely randomized factorial arrangement $(2 \times 2)$ consisting of two supplementation levels $\left(5\right.$ and $15 \mathrm{~g} \mathrm{~kg}^{-1}$ of BW) and two breeds (Morada Nova and Santa Inês) or two crosses (Dorper $\times$ Morada Nova and Dorper $\times$ Santa Inês). The ewes were weighed, their body condition was evaluated during pregnancy, and the weaning weight of the lambs at up to 70 days old was measured. There was no effect of breed or supplementation on the prolificacy or type of birth. The Santa Inês ewes had a faster rate of development, although the weight loss during lactation was lower in the Morada Nova ewes. The weight development of the Dorper $\times$ Santa Inês lambs during the maternal-dependent phase was $34 \mathrm{~g} / 100 \mathrm{~g}$ higher than that of the other cross, with no difference in the maternal-independent phase. Dorper $\times$ Santa Inês lambs gain more weight during the 70 days of development. However, the Dorper $\times$ Morada Nova lambs show a better response in terms of production efficiency when comparing the weight of the lambs with the weight of the sheep.
\end{abstract}

Key Words: crossbreeding, feed evaluation, performance

\section{Introduction}

The production of lamb meat contributes to the food supply in the semiarid region of Northeast Brazil, creates jobs and improves the quality of life of low-income populations. The economic importance of lamb-meat production is also because it uses little arable land. This system is extensive and is characterized by a high level of dependence on natural pastures and the use of non-specialized genotypes, resulting in low production rates, high mortality of young animals and a high slaughter age.

The Morada Nova and Santa Inês breeds are the main indigenous breeds of hair sheep in Northeastern Brazil, and they are bred mainly for the production of meat and skin. Their adaptations to the climatic conditions of the semiarid region include prolificacy, good feed conversion, and resistance mainly to endoparasitic infestation. Therefore, these animals are important for small farms, constituting

Received January 22, 2014 and accepted July 2, 2014

Corresponding author: ronaldooliveira@ufba.br

http://dx.doi.org/10.1590/S1516-35982014001000006

Copyright $($ C 2014 Sociedade Brasileira de Zootecnia. This is an Open Access article distributed under the terms of the Creative Commons Attribution Non-Commercial License, which permits unrestricted non-commercial use, distribution, and reproduction in any medium, provided the original work is properly cited. an essential source of protein in the diet of the rural population (Vilpoux et al., 2013). Thus, the genotypes conferring these adaptations are economically important in the sheep production systems, and, due to the increase in the consumer market, producers are interested and have invested in exploring and breeding these animals (Costa et al., 2012).

The use of inter-crosses has been proposed as a solution to reconcile the productivity and adaptability of sheep in these harsh environments. In selection programs, the use of breeds that are specialized for meat production in crosses with Santa Inês sheep significantly improves animal performance with respect to the large growth variability and carcass conformation of the Santa Inês breed (Carneiro et al., 2007; Biagiotti et al., 2013; Boujenane et al., 2013; Souza et al., 2013).

Additionally, the gestational period is characterized by an increase in live weight with reduction of the body condition of the animals with the evolution of the gestation. However, research results demonstrate that feeding ewes diets with higher total energy and crude protein during late gestation affects the performance of lambs at weaning. This is possible because a maternal diet greater in metabolizable protein during the last third of gestation would improve offspring growth due to enhanced placental or mammary 
gland function (Paim et al., 2013; Van Emon et al., 2014). Thus, the objective of this study was to evaluate the effect of concentrate supplementation in last third of gestation and during lactation on the weight gain of F1 Dorper $\times$ Morada Nova lambs and F1 Dorper $\times$ Santa Inês lambs reared in a creep-feeding system.

\section{Material and Methods}

The experiment was conducted at the Teaching Module Production of Sheep and Goats of Universidade Federal do Piauí - Technical College of Bom Jesus (CTBJ), which is located in Bom Jesus, Piauí State, Brazil. The duration of the study was 130 days, with 15 days of female adaptation to the diet, the last 45 days of pregnancy and 70 days of lamb follow-up; the follow-up period was divided into two parts: from birth to 28 days, termed maternaldependent, and from day 28 to 70 , termed maternalindependent.

Thirty-six sheep in the last third of pregnancy were used. Of these, eighteen Morada Nova and eighteen Santa Inês ewes were artificially inseminated with semen from Dorper ram. After the artificial insemination was performed, the pregnancy was diagnosed by trans-rectal ultrasound and preventative health management ensued, including deworming and vaccination against enterotoxemia. In the experiment, 32 lambs were used: thirteen from the Dorper $\times$ Morada Nova crosses and nineteen from the Dorper $\times$ Santa Inês crosses.

The females remained on pasture, grazing Andropogon gayanus. The ewes were collected in the late afternoon and separated into individual covered stalls where they received concentrate supplementation (Table 1) according to their weight (5 and $15 \mathrm{~g} \mathrm{~kg}^{-1}$ of body weight; BW), which was adjusted weekly.

From the 7th day of life, the lambs were also divided into two treatment groups receiving different levels of concentrate supplementation (5 and $15 \mathrm{~g} \mathrm{~kg}^{-1}$ of BW; Table 2), which was formulated for a weight gain of $200 \mathrm{~g} \mathrm{~d}^{-1}$ (NRC, 2007) on a creep-feeding system with openings of $17 \mathrm{~cm}$, which allowed only for the entry of the lambs and was kept in an area near water. The feed was supplied daily and the daily remains were recorded.

The lambs remained on stable to maternity until the 7th day of life, when they were identified by a numbered necklace and moved with their mothers to paddocks on the Andropogon gayanus pasture. The lambs were weighed weekly from birth and weaned (at 75 days) to reach $16 \mathrm{~kg} \mathrm{BW}$. All of the animals received treatment for the control and prevention of endoparasites (a $2 \mathrm{~mL}$ dose of hydrochloride disophenol plus an additional $1 \mathrm{ml}$ per $4 \mathrm{~kg}$ BW) with a booster given every 20 days. After delivery, the lambs were weighed and had their navels disinfected with iodine $(10 \mathrm{~g} / 100 \mathrm{~g})$.

The ewes were distributed in a completely randomized design in a $2 \times 2$ factorial arrangement consisting of two supplementation levels (5 and $15 \mathrm{~g} \mathrm{~kg}^{-1}$ of BW) and two breeds (Santa Inês and Morada Nova). The lambs were distributed in a completely randomized design in a $2 \times 2$ factorial arrangement consisting of two supplementation levels (5 and $15 \mathrm{~g} \mathrm{~kg}^{-1}$ of BW) and two crosses (Dorper $\times$ Santa Inês and Dorper $\times$ Morada Nova). Statistical analyses were performed using the ANOVA procedure on SAS (Statistical Analysis System, version 9.4). The means were

Table 2 - Ingredient and chemical composition of the experimental concentrate (dry matter basis) fed to lambs with selective access to feeders

\begin{tabular}{|c|c|}
\hline Item & $\left(\mathrm{g} \mathrm{kg}^{-1}\right.$ of $\left.\mathrm{DM}\right)$ \\
\hline \multicolumn{2}{|l|}{ Ingredient } \\
\hline Corn meal & 750.0 \\
\hline Soybean meal & 200.0 \\
\hline Mineral supplement ${ }^{1}$ & 50.0 \\
\hline Composition & $\left(\mathrm{g} \mathrm{kg}^{-1}\right.$ of DM) \\
\hline Dry matter & 895.0 \\
\hline Crude protein & 176.0 \\
\hline Metabolizable energy (Mcal kg ${ }^{-1}$ of DM) & 3.14 \\
\hline Ether extract & 29.8 \\
\hline Neutral detergent fiber & 83.0 \\
\hline Acid detergent fiber & 38.5 \\
\hline Calcium & 5.6 \\
\hline Phosphorus & 6.4 \\
\hline
\end{tabular}

DM - dry matter.

${ }^{1}$ Mineral supplement: $10 \mathrm{mg}$ cobalt, $10 \mathrm{mg}$ copper, $2.5 \mathrm{mg}$ iodine, $580 \mathrm{mg}$ manganese, $0.9 \mathrm{mg}$ selenium, $270 \mathrm{mg}$ zinc and $150 \mathrm{mg}$ iron.

Table 1 - Chemical composition of the ingredients of the concentrate fed to the experimental ewes

\begin{tabular}{lcccccc}
\hline \multirow{2}{*}{ Ingredient } & \multicolumn{5}{c}{ Chemical composition $\left(\mathrm{g} \mathrm{kg}^{-1}\right.$ of DM) } \\
\cline { 2 - 7 } & $\mathrm{DM}$ & $\mathrm{CP}$ & $\mathrm{EE}$ & $\mathrm{TDN}$ & $\mathrm{Ca}$ & $\mathrm{P}$ \\
\hline Corn meal & 871.9 & 99.8 & 51.9 & 675.0 & 00.5 & 4.9 \\
Soybean meal $_{\text {Mineral supplement }}{ }^{1}$ & 884.8 & 487.6 & 17.5 & 807.3 & 03.3 & 5.7 \\
Concentrate & 979.1 & - & - & - & 180.0 & 130.0 \\
\hline
\end{tabular}

DM - dry matter; CP - crude protein; EE - ether extract; TDN - total digestible nutrients; Ca - calcium; P - phosphorus.

${ }^{1}$ Mineral supplement: $10 \mathrm{mg}$ cobalt, $10 \mathrm{mg}$ copper, $2.5 \mathrm{mg}$ iodine, $580 \mathrm{mg}$ manganese, $0.9 \mathrm{mg}$ selenium, $270 \mathrm{mg}$ zinc and $150 \mathrm{mg}$ iron. 
compared using the $\mathrm{F}$ test with $\alpha=0.05$ and adopted the following mathematical model:

$$
\mathrm{y}_{i j k}=\mu+\tau_{i}+\beta_{j}+(\tau \beta)_{i j}+\varepsilon_{i j k}
$$

in which $\mathrm{y}_{i j k}=$ dependent variables; $\mu=$ overall mean; $\tau_{i}=$ effect of $i$-th supplementation level ( $i=5$ or $15 \mathrm{~g} \mathrm{~kg}^{-1}$ of $\mathrm{BW}) ; \beta_{j}=$ effect of the $j$-th genetic group $(j=$ Santa Inês or Morada Nova; Dorper $\times$ Santa Inês or Dorper $\times$ Morada Nova); $(\tau \beta)_{i j}=$ effect of the interaction between the $i$-th supplementation level and $j$-th genetic group; and $\varepsilon_{i j k}=$ random error associated with the $k$-th replicate in cell $(i, j)$.

\section{Results}

There was no effect of breed or concentrate supplementation on the type of birth or prolificacy of the ewes $(\mathrm{P}>0.05)$ (Table 3$)$.

A significant effect of the breed was observed on the body weight at calving, weaning weight and weight loss during lactation $(\mathrm{P}<0.05)$. Between the levels of supplementation, there was a significant effect $(\mathrm{P}<0.05)$ on the body condition score of the mother at weaning and on the weight loss during lactation.
The Santa Inês ewes had a higher rate of body development $(\mathrm{P}<0.05)$ compared with the Morada Nova ewes. However, the weight loss during lactation was lower in the Morada Nova ewes, influenced by the fact that Santa Inês lambs have a greater body size and greater nutrient requirements during this phase. Regarding the levels of supplementation, the sheep that received the highest level of supplementation had a higher $(\mathrm{P}<0.05)$ body condition score at weaning, most likely because they were able to deposit more fat during lactation, with more highly resilient body reserves.

The weight loss during lactation was lower $(\mathrm{P}<0.05)$ in the Morada Nova ewes, most likely due to the lower body condition of this breed. Mothers which received lower amounts of concentrate supplementation $\left(5 \mathrm{~g} \mathrm{~kg}^{-1}\right.$ of BW) lost $3.0 \mathrm{~kg} \mathrm{~d}^{-1}$ of BW more than did the other group (15 $\mathrm{g} \mathrm{kg}^{-1}$ of $\mathrm{BW}$ ), representing an increase of $56 \mathrm{~g} / 100 \mathrm{~g}$. There was a significant effect $(\mathrm{P}<0.05)$ for interaction between breed and level of supplementation; only the variable weight loss during lactation $(\mathrm{kg})$ was influenced by the lower level of supplementation for the Santa Inês breed ( $5 \mathrm{~g} \mathrm{~kg}^{-1}$ of BW).

Table 3 - Effect of concentrate supplementation during the last third of gestation and lactation on performance of Morada Nova (MN) and Santa Inês (SI) ewes from calving to weaning

\begin{tabular}{|c|c|c|c|c|c|c|c|c|}
\hline \multirow{2}{*}{ Variable } & \multicolumn{2}{|c|}{ Breed } & \multicolumn{2}{|c|}{ Supplementation $\left(\mathrm{g} \mathrm{kg}^{-1}\right.$ of BW) } & \multirow{2}{*}{ SEM } & \multicolumn{3}{|c|}{ P-value } \\
\hline & $\mathrm{MN}$ & SI & 5 & 15 & & $\mathrm{~B}$ & $\mathrm{~S}$ & $\mathrm{~B} \times \mathrm{S}$ \\
\hline Type of birth ${ }^{1}$ & $1.69 \mathrm{a}$ & $1.42 \mathrm{a}$ & $1.52 \mathrm{a}$ & $1.53 \mathrm{a}$ & 0.10 & $0.1618 \mathrm{~ns}$ & $0.9745 \mathrm{~ns}$ & $0.1194 \mathrm{~ns}$ \\
\hline Prolificacy & $1.25 \mathrm{a}$ & $1.60 \mathrm{a}$ & $1.27 \mathrm{a}$ & $1.71 \mathrm{a}$ & 0.11 & $0.0956 \mathrm{~ns}$ & $0.1062 \mathrm{~ns}$ & $0.1108 \mathrm{~ns}$ \\
\hline Body weight at calving (kg) & $29.66 b$ & $52.2 \mathrm{a}$ & $44.83 \mathrm{a}$ & $40.44 a$ & 1.22 & $<.0001^{*}$ & $0.8129 \mathrm{~ns}$ & $0.8015 \mathrm{~ns}$ \\
\hline BCS at calving & $2.65 \mathrm{a}$ & $2.52 \mathrm{a}$ & $2.39 \mathrm{a}$ & $2.84 \mathrm{a}$ & 0.08 & $0.9609 \mathrm{~ns}$ & $0.0747 \mathrm{~ns}$ & $0.5430 \mathrm{~ns}$ \\
\hline Body weight at weaning $(\mathrm{kg})$ & $28.30 \mathrm{~b}$ & $45.86 a$ & $39.27 \mathrm{a}$ & $37.96 a$ & 1.15 & $0.0093 *$ & $0.6417 \mathrm{~ns}$ & $0.3740 \mathrm{~ns}$ \\
\hline BCS at weaning & $2.57 \mathrm{a}$ & $2.36 \mathrm{a}$ & $2.21 b$ & $2.80 \mathrm{a}$ & 0.10 & $0.8044 \mathrm{~ns}$ & $0.0097 *$ & $0.2134 \mathrm{~ns}$ \\
\hline Weight loss during lactation $\left(\mathrm{kg} \mathrm{d}^{-1}\right)$ & $1.35 \mathrm{~b}$ & $6.34 \mathrm{a}$ & $5.57 \mathrm{a}$ & $2.47 \mathrm{~b}$ & 0.44 & $0.0009 *$ & $0.0116^{*}$ & $0.0153 *$ \\
\hline
\end{tabular}

${ }^{1}$ Type of birth $(1=$ single; $2=$ double; 3 = triple); B - breed; $\mathrm{S}$ - supplementation; $\mathrm{BW}$ - body weight; BCS - body condition score $(1=$ emaciated, very thin; 2 = thin; $3=$ average "good shape"; 4 = fat; 5 = obese, very fat); SEM - standard error of the mean.

Different letters in the same row when compared between breed and level of supplementation and their interaction differ at probability of $5 \% ; *$ significant at $5 \%$ of probability; ns - not significant.

Table 4 - Growth performance of crossbred lambs (Dorper (D) $\times$ Morada Nova $(M N)$ and Dorper $(D) \times$ Santa Inês, $($ SI) $)$ supplemented during the maternal-dependent phase (from birth to 28 days)

\begin{tabular}{|c|c|c|c|c|c|c|c|c|}
\hline \multirow{2}{*}{ Variable } & \multicolumn{2}{|c|}{ Crossbreed } & \multicolumn{2}{|c|}{ Supplementation $\left(\mathrm{g} \mathrm{kg}^{-1}\right.$ of BW) } & \multirow{2}{*}{ SEM } & \multicolumn{3}{|c|}{ P-value } \\
\hline & $\mathrm{D} \times \mathrm{MN}$ & $\mathrm{D} \times \mathrm{SI}$ & 5 & 15 & & $\mathrm{C}$ & $\mathrm{S}$ & $\mathrm{C} \times \mathrm{S}$ \\
\hline Body weight at birth (kg) & $2.83 b$ & $3.62 \mathrm{a}$ & $3.24 \mathrm{a}$ & $3.40 \mathrm{a}$ & 0.10 & $0.0020 *$ & $0.2382 \mathrm{~ns}$ & $0.3020 \mathrm{~ns}$ \\
\hline Body weight at 7 days (kg) & $3.53 b$ & $5.12 \mathrm{a}$ & $4.39 \mathrm{a}$ & $4.60 \mathrm{a}$ & 0.20 & $0.0008 *$ & $0.2958 \mathrm{~ns}$ & $0.1935 \mathrm{~ns}$ \\
\hline ADG at 7 days $\left(\mathrm{kg} \mathrm{d}^{-1}\right)$ & $0.70 \mathrm{~b}$ & $1.50 \mathrm{a}$ & $1.15 \mathrm{a}$ & $1.20 \mathrm{a}$ & 0.02 & $0.0057^{*}$ & $0.5364 \mathrm{~ns}$ & $0.2228 \mathrm{~ns}$ \\
\hline Body weight at 14 days (kg) & $4.20 \mathrm{~b}$ & $6.35 \mathrm{a}$ & $5.32 \mathrm{a}$ & $5.71 \mathrm{a}$ & 0.27 & $0.0005^{*}$ & $0.1911 \mathrm{~ns}$ & $0.2439 \mathrm{~ns}$ \\
\hline ADG at 14 days $\left(\mathrm{kg} \mathrm{d}^{-1}\right)$ & $0.66 b$ & $1.23 \mathrm{a}$ & $0.92 \mathrm{a}$ & $1.11 \mathrm{a}$ & 0.02 & $0.0197 *$ & $0.2331 \mathrm{~ns}$ & $0.7120 \mathrm{~ns}$ \\
\hline Body weight at 21 days (kg) & $5.06 \mathrm{~b}$ & $7.86 \mathrm{a}$ & $6.50 \mathrm{a}$ & $7.06 \mathrm{a}$ & 0.35 & $<.0001 *$ & $0.1304 \mathrm{~ns}$ & $0.0877 \mathrm{~ns}$ \\
\hline ADG at 21 days $\left(\mathrm{kg} \mathrm{d}^{-1}\right)$ & $0.86 b$ & $1.51 \mathrm{a}$ & $1.17 \mathrm{a}$ & $1.35 \mathrm{a}$ & 0.01 & $0.0069^{*}$ & $0.3148 \mathrm{~ns}$ & $0.0632 \mathrm{~ns}$ \\
\hline Body weight at 28 days (kg) & $6.06 \mathrm{~b}$ & $9.00 \mathrm{a}$ & $7.42 \mathrm{a}$ & $8.38 \mathrm{a}$ & 1.42 & $0.0002 *$ & $0.0695 \mathrm{~ns}$ & $0.1018 \mathrm{~ns}$ \\
\hline ADG at 28 days $\left(\mathrm{kg} \mathrm{d}^{-1}\right)$ & $1.00 \mathrm{a}$ & $1.13 \mathrm{a}$ & $0.92 \mathrm{a}$ & $1.31 \mathrm{a}$ & 0.05 & $0.2985 \mathrm{~ns}$ & $0.0788 \mathrm{~ns}$ & $0.6084 \mathrm{~ns}$ \\
\hline Total weight gain (kg) & $3.96 \mathrm{~b}$ & $6.05 \mathrm{a}$ & $5.08 \mathrm{a}$ & $5.33 \mathrm{a}$ & 1.30 & $0.0007 *$ & $0.1551 \mathrm{~ns}$ & $0.1231 \mathrm{~ns}$ \\
\hline
\end{tabular}

BW - body weight; ADG - average daily gain; S - supplementation; C - crossbreed; SEM - standard error of the mean.

Different letters in the same row when compared between breed and level of supplementation and their interaction differ at probability of $5 \%$; * significant at $5 \%$ of probability; ns - not significant. 
There was a significant effect $(\mathrm{P}<0.05)$ of the breed on the weight gain at 7,14 and 21 days, as well as on the total weight gain during the maternal-dependent phase. However, the level of supplementation did not affect $(\mathrm{P}>0.05)$ the weight gain or development of lambs during the first 28 days (Table 4).

The weight gain of Dorper $\times$ Santa Inês crossbred lambs during the maternal-dependence phase was $34 \mathrm{~g} / 100 \mathrm{~g}$ higher $(\mathrm{P}>0.05)$ than that of Dorper $\times$ Morada Nova crossbred lambs, regardless of the treatment to which they were subjected. This increase occurred due to physiological influences that promote higher growth rates in Santa Inês sheep; therefore, the Dorper $\times$ Santa Inês crossbred lambs were born heavier and developed quite quickly.

There was no significant effect $(\mathrm{P}>0.05)$ for interaction between breed and level of supplementation for variables during the maternal-dependent phase (from birth to 28 days).

During the maternal-independent (i.e., post-weaning) phase, the weight gain of the Morada Nova lambs matched $(\mathrm{P}>0.05)$ that of the Santa Inês lambs, demonstrating the efficiency of the Morada Nova breed to convert the concentrate intake into meat. Nevertheless, there was a significant effect $(\mathrm{P}<0.05)$ of the breed on the body weight, wherein the Dorper $\times$ Santa Inês crossbred lambs continued to show superior weight gain compared with the Dorper $\times$ Morada Nova crossbred lambs (Table 5).

There was no significant effect $(\mathrm{P}>0.05)$ for interaction between breed and level of supplementation on the variables during the maternal-independent phase (from 28 to 70 days).

Regarding values related to production efficiency versus live weight of the lambs and their dams (Table 6), there was a significant effect $(\mathrm{P}<0.05)$ of the breed on all of the tested variables. Among the levels of supplementation, a significant effect was observed only between the live weight of the lamb at weaning and the weight of the mother at birth.

The average concentrate intake of the lambs during lactation was $190 \mathrm{~g} \mathrm{~d}^{-1}$, producing a daily weight gain of 135.33 and $185.33 \mathrm{~g} \mathrm{~d}^{-1}$ for Dorper $\times$ Morada Nova and Dorper $\times$ Santa Inês crossbred lambs, respectively. These weight gains could be higher, as this experiment was conducted during the dry season, when the quality and availability of pasture were limited.

Table 5 - Growth performance of crossbred lambs (Dorper (D) $\times$ Morada Nova $(\mathrm{MN})$ and Dorper $(\mathrm{D}) \times$ Santa Inês $(\mathrm{SI}))$ supplemented during the maternal-independent phase (from 28 to 70 days)

\begin{tabular}{|c|c|c|c|c|c|c|c|c|}
\hline \multirow{2}{*}{ Variable } & \multicolumn{2}{|c|}{ Crossbreed } & \multicolumn{2}{|c|}{ Supplementation $\left(\mathrm{g} \mathrm{kg}^{-1}\right.$ of BW) } & \multirow{2}{*}{ SEM } & \multicolumn{3}{|c|}{ P-value } \\
\hline & $\mathrm{D} \times \mathrm{MN}$ & $\mathrm{D} \times \mathrm{SI}$ & 5 & 15 & & $\mathrm{C}$ & $\mathrm{S}$ & $\mathrm{C} \times \mathrm{S}$ \\
\hline Body weight at 35 days (kg) & $6.80 \mathrm{~b}$ & $9.92 \mathrm{a}$ & $8.32 \mathrm{a}$ & $9.13 \mathrm{a}$ & 0.45 & $0.0007 *$ & $0.1551 \mathrm{~ns}$ & $0.1231 \mathrm{~ns}$ \\
\hline ADG at 35 days $\left(\mathrm{kg} \mathrm{d}^{-1}\right)$ & $0.73 \mathrm{a}$ & $0.91 \mathrm{a}$ & $0.75 \mathrm{a}$ & $0.90 \mathrm{a}$ & 0.01 & $0.4391 \mathrm{~ns}$ & $0.5762 \mathrm{~ns}$ & $0.5033 \mathrm{~ns}$ \\
\hline Body weight at 42 days (kg) & $7.78 \mathrm{~b}$ & $11.20 \mathrm{a}$ & $9.32 \mathrm{a}$ & $10.53 \mathrm{a}$ & 0.52 & $0.0007 *$ & $0.0910 \mathrm{~ns}$ & $0.1404 \mathrm{~ns}$ \\
\hline ADG at 42 days $\left(\mathrm{kg} \mathrm{d}^{-1}\right)$ & $0.98 \mathrm{a}$ & $1.28 \mathrm{a}$ & $1.00 \mathrm{a}$ & $1.39 \mathrm{a}$ & 0.01 & $0.0609 \mathrm{~ns}$ & $0.3740 \mathrm{~ns}$ & $0.6678 \mathrm{~ns}$ \\
\hline Body weight at 49 days (kg) & $9.01 \mathrm{~b}$ & $12.53 \mathrm{a}$ & $10.58 \mathrm{a}$ & $11.86 \mathrm{a}$ & 0.60 & $0.0018^{*}$ & $0.1185 \mathrm{~ns}$ & $0.1623 \mathrm{~ns}$ \\
\hline ADG at 49 days $\left(\mathrm{kg} \mathrm{d}^{-1}\right)$ & $1.23 \mathrm{a}$ & $1.33 \mathrm{a}$ & $1.25 \mathrm{a}$ & $1.33 \mathrm{a}$ & 0.01 & $0.5961 \mathrm{~ns}$ & $0.7248 \mathrm{~ns}$ & $0.6265 \mathrm{~ns}$ \\
\hline Body weight at 56 days (kg) & $9.91 b$ & $13.56 \mathrm{a}$ & $11.38 \mathrm{a}$ & $13.10 \mathrm{a}$ & 0.67 & $0.0023 *$ & $0.0707 \mathrm{~ns}$ & $0.2399 \mathrm{~ns}$ \\
\hline ADG at 56 days $\left(\mathrm{kg} \mathrm{d}^{-1}\right)$ & $0.90 \mathrm{a}$ & $1.03 \mathrm{a}$ & $0.80 \mathrm{a}$ & $1.23 \mathrm{a}$ & 0.01 & $0.3095 \mathrm{~ns}$ & $0.2345 \mathrm{~ns}$ & $0.4363 \mathrm{~ns}$ \\
\hline Body weight at 63 days (kg) & $11.10 \mathrm{~b}$ & $14.38 \mathrm{a}$ & $12.38 \mathrm{a}$ & $14.01 \mathrm{a}$ & 0.62 & $0.0067 *$ & $0.1073 \mathrm{~ns}$ & $0.2523 \mathrm{~ns}$ \\
\hline ADG at 63 days $\left(\mathrm{kg} \mathrm{d}^{-1}\right)$ & $0.81 \mathrm{a}$ & $1.18 \mathrm{a}$ & $0.90 \mathrm{a}$ & $1.00 \mathrm{a}$ & 0.01 & $0.1899 \mathrm{~ns}$ & $0.5331 \mathrm{~ns}$ & $0.9414 \mathrm{~ns}$ \\
\hline Body weight at 70 days $(\mathrm{kg})$ & $11.97 \mathrm{~b}$ & $15.56 \mathrm{a}$ & $15.26 \mathrm{a}$ & $15.33 \mathrm{a}$ & 0.67 & $0.0050 *$ & $0.0703 \mathrm{~ns}$ & $0.1828 \mathrm{~ns}$ \\
\hline ADG at 70 days $\left(\mathrm{kg} \mathrm{d}^{-1}\right)$ & $0.87 \mathrm{a}$ & $1.18 \mathrm{a}$ & $0.87 \mathrm{a}$ & $1.32 \mathrm{a}$ & 0.01 & $0.0711 \mathrm{~ns}$ & $0.0793 \mathrm{~ns}$ & $0.1285 \mathrm{~ns}$ \\
\hline Total weight gain (kg) & $6.19 \mathrm{a}$ & $7.85 \mathrm{a}$ & $5.72 \mathrm{a}$ & $9.03 \mathrm{a}$ & 0.60 & $0.5438 \mathrm{~ns}$ & $0.4584 \mathrm{~ns}$ & $0.3181 \mathrm{~ns}$ \\
\hline
\end{tabular}

BW - body weight; ADG - average daily gain; S - supplementation; C - crossbreed; SEM - standard error of the mean.

Different letters in the same row when compared between breed and level of supplementation and their interaction differ at probability of $5 \%$; significant at $5 \%$ of probability; ns - not significant.

Table 6 - Means and P-value observed for the production efficiency of lambs in relation to the body weight of the mothers at birth and at weaning

\begin{tabular}{|c|c|c|c|c|c|c|c|c|}
\hline \multirow[t]{2}{*}{ Variable } & \multicolumn{2}{|c|}{ Crossbreed } & \multicolumn{2}{|c|}{$\begin{array}{c}\text { Supplementation } \\
\left(\mathrm{g} \mathrm{kg}^{-1} \text { of } \mathrm{BW}\right)\end{array}$} & \multirow[t]{2}{*}{ SEM } & \multicolumn{3}{|c|}{ P-value } \\
\hline & $\mathrm{D} \times \mathrm{MN}$ & $\mathrm{D} \times \mathrm{SI}$ & 5 & 15 & & $\mathrm{C}$ & $\mathrm{S}$ & $\mathrm{C} \times \mathrm{S}$ \\
\hline BW lamb at birth/BW mother at birth $\left(\mathrm{g} \mathrm{kg}^{-1}\right)$ & $95.6 \mathrm{a}$ & $72.2 b$ & $77.8 \mathrm{a}$ & $87.3 \mathrm{a}$ & 3.07 & $0.0055^{*}$ & $0.0503 \mathrm{~ns}$ & $0.1292 \mathrm{~ns}$ \\
\hline BW lamb at weaning/BW mother at birth $\left(\mathrm{g} \mathrm{kg}^{-1}\right)$ & $440.3 \mathrm{a}$ & $321.3 b$ & $337.4 \mathrm{~b}$ & $416.8 \mathrm{a}$ & 15.57 & $0.0145^{*}$ & $0.0206^{*}$ & $0.0254 *$ \\
\hline BW lamb at weaning/BW mother at weaning $\left(\mathrm{g} \mathrm{kg}^{-1}\right)$ & $464.5 \mathrm{a}$ & $339.8 b$ & $374.3 \mathrm{a}$ & $414.1 \mathrm{a}$ & 17.26 & $0.0195 *$ & $0.8097 \mathrm{~ns}$ & $0.8944 \mathrm{~ns}$ \\
\hline
\end{tabular}

BW - body weight; S - supplementation; D - Dorper; MN - Morada Nova; SI - Santa Inês; C - crossbreed; SEM - standard error of the mean.

Different letters in the same row when compared between breed and level of supplementation and their interaction differ at probability of $5 \%$; significant at $5 \%$ of probability; ns - not significant. 
There was a significant effect $(\mathrm{P}>0.05)$ of the interaction between breed and supplementation level on lamb BW at weaning/mother BW at birth, as the weight gain was greater in the Dorper $\times$ Morada Nova crossbred animals that received the highest level of supplementation $\left(15 \mathrm{~g} \mathrm{~kg}^{-1} \mathrm{BW}\right)$.

\section{Discussion}

In most studies reviewed, it is common to conclude that the type of birth affects the weight gain of lambs and that lambs resulting from a single birth are larger and heavier compared with those from twin and triplet births. This fact has been observed in several studies with lambs from different genetic groups (Rocha et al., 2009; Mohammadi et al., 2010; Castro et al., 2012; Koritiaki et al., 2012). The main reason for this occurrence, according to the authors, is that twin lambs are lighter during the pre-weaning stage due to competition for nutrients in utero and after birth. Although sheep birthing two or three lambs have a higher production of milk, this higher production does not equate to double the output of a sheep birthing a single lamb; thus, twin lambs individually consume smaller quantities of milk.

The supplementation of ewes during pregnancy results in higher body condition score at weaning, most likely because they were able to deposit more fat during lactation, with more resilient body reserves. At the end of pregnancy, the nutrient demand increases, as $60 \mathrm{~g} / 100 \mathrm{~g}$ of fetal growth occurs during this period. At this stage, an inappropriate dietary regimen, along with the presence of two or more fetuses, may cause toxemia of pregnancy (Linzmeier and Avanza, 2009). However, during lactation, nutrition deserves more attention because during this period the female encounters at least three situations with distinct nutritional needs. In the first situation, which usually occurs during the first weeks postpartum, the ewe has a negative energy balance because milk production is increasing and intake has not yet reached its full potential, thus usually mobilizing the body reserves. In the second situation, the energy balance is zero, as the milk production is already declining and females have reached the peak dry matter intake. In the third situation, the energy balance is positive, and the body reserves are replenished (Resende et al., 2008; Tedeschi et al., 2010), as observed in the present study.

The weight loss in early lactation is a normal event during the first abovementioned situation when a negative energy balance occurs, mobilizing adipose tissue and even muscle tissue reserves. However, special attention should be paid to the negative energy balance, as it can adversely affect milk production, lamb growth and subsequent reproductive performance, especially when working with reproductive programs aiming at more than one calving year (NRC, 2007). The sheep in this study presented good body conditions during lactation, which allowed for a speedy recovery and for an ideal weight and body condition for mating soon after.

According to Costa et al. (2012), the Morada Nova sheep may undergo a later growth when compared with the Santa Inês sheep. As the maternal genetic basis was different, the greatest weight gain in the first days was observed in the Dorper $\times$ Santa Inês crossbred lambs, most likely due to the superiority of the Santa Inês breed, which is specialized for meat production, plus the heterosis of the cross (Amaral et al., 2011a; Amaral et al., 2011b). The weight gain from birth to weaning is strongly influenced by non-additive genetic effects, such as individual and maternal heterosis and recombination. However, we must consider the maternal effect of the Santa Inês breed, as the maternal effect greatly influences growth characteristics, particularly at weaning (Sousa et al., 2006).

Maternal effects directly influence the lambs during the maternal-dependent phase, and milk production is the determining factor, (Table 5). According to Castro et al. (2012), it is important to consider the effect of the nutritional energy level of the sheep, because this level influences lamb development, which may affect the efficiency of the production system. Additionally, it is important to consider other environmental factors that affect the growth characteristics of the sheep by affecting gene expression.

However, as the lambs were growing (as already noted in the weight gain at 28 days [maternal-dependent stage]), their dependence on milk decreased and the Dorper $x$ Morada Nova lambs presented the same conditions as those of the Santa Inês lambs, having managed to efficiently convert the food that was provided in the trough. According to Costa et al. (2012), one of the main factors that raise the average daily weight gain of lambs is the inclusion of concentrate in the diet.

The Dorper $\times$ Morada Nova crossbred lambs showed a greater weight gain in relation to body weight of the mother at birth and weaning compared with the Santa Inês lambs. This fact reflects the productive and reproductive capacity of the Santa Inês breed. When comparing the level of supplementation, regardless of breed, there was a significant difference in the live weight of lambs at weaning in relation to the weight of the mother at birth, which is correlated with the fact that weaning lambs received a considerable amount of supplementation through creep feeding.

The use of creep feeding promoted a greater weight gain during the growth period, increasing the average daily gain (ADG) of the lambs by $23 \mathrm{~g} / 100 \mathrm{~g}$. This weight gain 
can justify the use of this technology to provide the largest batch earliness, improved feed efficiency and weight gain, and ease of adaptation to the feedlot (Biagiotti et al., 2013; Souza et al., 2013; Rech et al., 2014).

This method has proven effective in reducing the age at slaughter of lambs. Additionally, the lambs of twin births can also benefit, having a development similar to that of single-born lambs without supplementation. In addition to promoting a lower calving interval, creep feeding promotes a lower overhead of breastfeeding, thus raising the reproductive efficiency, and can compensate for low milk production or poor maternal ability of the ewes (Poli et al., 2008; Nascimento et al., 2012; Silva et al., 2012).

\section{Conclusions}

Supplying concentrate supplementation to ewes in the amount of $15 \mathrm{~g} \mathrm{~kg}^{-1}$ of their body weight reduces the negative energy balance, as represented by the decrease in the reduction of the body condition score until weaning and reduced weight loss during lactation.

Dorper $\times$ Santa Inês crossbred lambs gain more weight during the 70 days of development as compared with Dorper $\times$ Morada Nova crossbred lambs.

After weaning, concentrated supplementation provides the Dorper $\times$ Morada Nova crossbred lambs with a weight gain that is similar to that of the Dorper $\times$ Santa Inês crossbred lambs and a better response in terms of production efficiency.

\section{References}

Amaral, R. M.; Macedo, F. A. F.; Macedo, F. G.; Lino, D. A.; Alcalde, C. R.; Dias, F.B. and Gualda, T. P. 2011a. Tissue deposition in Santa Inês, $1 / 2$ Dorper-Santa Inês and $1 / 2$ White Dorper-Santa Inês lambs assessed by ultrasonography. Revista Brasileira de Saúde e Produção Animal 12:658-669.

Amaral, R. M.; Macedo, F. A. F.; Alcalde, C. R.; Lino, D. A.; Bánkuti, F. I.; Macedo, F. G.; Dias, F. B. and Gualda, T. P. 2011 b. Productive performance and economical analysis of confined lambs slaughtered with three fat thicknesses. Revista Brasileira de Saúde e Produção Animal 12:155-165.

Biagiotti, D.; Sarmento, J. L. R.; Ó, A. O.; Rêgo Neto, A. A.; Santos, G. V.; Santos, N. P. S.; Torres, T. S. and Neri, V. S. 2013. Phenotypic characterization of Santa Inês sheep in the State of Piauí. Revista Brasileira de Saúde e Produção Animal 140:29-42.

Boujenane, I.; Chikhi, A.; Lakcher, O. and Ibnelbachyr, M. 2013. Genetic and environmental factors affecting perinatal and preweaning survival of D'man lambs. Tropical Animal Health and Production 45:1391-1397.

Carneiro, P. L.; Malhado, C. H. M.; Souza Júnior, A. A. O.; Silva, A. G. S.; Santos, F. N.; Santos, P. F. and Paiva, S. R. 2007. Growth rate and phenotypic diversity among crosses of Dorper ovines and local breeds. Pesquisa Agropecuária Brasileira 42:991-998.
Castro, F. A. B.; Ribeiro, E. L. A.; Koritiaki, N. A.; Mizubuti, I. Y.; Silva, L. D. F.; Pereira, E. S.; Pinto, A. P.; Constantino, C. and Fernandes Junior, F. 2012. Performance from birth to weaning of Santa Inês lambs born to ewes fed different levels of energy. Semina: Ciências Agrárias 33:3379-3388.

Costa, D. S.; Costa, M. D.; Silva, F. V.; Rocha Júnior, V. R.; Carvalho, Z. G.; Tolentino, D. C. and Leite, J. R. A. 2012. Growth rate of Santa Inês and F1 Dorper Santa Inês in natural pasture. Revista Brasileira de Saúde e Produção Animal 13:237-243.

Koritiaki, N. A.; Ribeiro, E. L. A.; Scerbo, D. C.; Mizubuti, I. Y; Silva, L. D. F.; Barbosa, M. A. A. F.; Souza, C. L. and Paiva, F. H. P. 2012. Factors that affect the performance from birth to weaning on purebred and crossbred Santa Ines lambs. Revista Brasileira de Saúde e Produção Animal 13:258-270.

Linzmeier, L. G. and Avanza, M. F. B. 2009. Toxemia of pregnancy. Revista Científica Eletrônica de Medicina Veterinária 12:1-6.

Mohammadi, K.; Nassiri, M. T. B.; Fayazi, J. and Roshanfekr, H. 2010. Investigation of environmental factors influence on preweaning growth traits in Zandi lambs. Journal of Animal and Veterinary Advances 9:1011-1014.

Nascimento, E. N.; Rogério, M. C. P.; Batista, A. S. M.; Carneiro, M. S. S.; Vasconcelos, A. M.; Leite, E. R.; Landim, A. V.; Silva, V. L.; Costa, J. B. and Costa, H. H. A. 2012. Nutrient intake and quantitative aspects of carcass of finishing sheep fed with diets containing cashew nut meal. Revista Brasileira de Saúde e Produção Animal 13:1099-1111.

NRC - National Research Council. 2007. Nutrient requirements of small ruminants: sheep, goats, cervids, and new world camelids. 1.ed. National Academy Press, Washington, D.C.

Paim, T. P.; Silva, A. F.; Martins, R. F. S.; Borges, B. O.; Lima, P. M. T.; Cardoso, C. C.; Esteves, G. I. F.; Louvandinia, H. and McManus, C. 2013. Performance, survivability and carcass traits of crossbred lambs from five paternal breeds with local hair breed Santa Inês ewes. Small Ruminant Research 112:28-34.

Poli, C. H. E. C.; Monteiro, A. L. G.; Barros, C. S.; Moraes, A.; Fernandes, M. A. M. and Piazzetta, H. V. L. 2008. Meat sheep production on four different production systems. Revista Brasileira de Zootecnia 37:666-673.

Rech, C. L. S.; Rech, J. L.; Fischer, V.; Wiegand, M. M.; Moreira, H. L. M.; Osório, M. T. M. and Siewerdt, F. 2014. Body development, carcass, and meat quality of confined lambs fed increasing levels of whole rice meal. Tropical Animal Health and Production 46:191-195. doi: 10.1007/s11250-013-0474-4.

Resende, K. T.; Silva, H. O.; Lima, L. D. and Teixeira, I. A. M. A. 2008. Avaliação das exigências nutricionais de pequenos ruminantes pelos sistemas de alimentação recentemente publicados. Revista Brasileira de Zootecnia 37(supl. especial):161-177.

Rocha, L. P.; Fraga, A. B.; Araújo Filho, J. T.; Figueira, R. F.; Pacheco, K. M. G.; Silva, F. L. and Rodrigues, D. S. 2009. Performance of crossbred lambs in Alagoas, Brazil. Archivos de Zootecnia $58: 145-148$.

Silva, C. J. A.; Monteiro, A. L. G.; Fernandes, S. R.; Poli, C. H. E. C.; Prado, O. R. and Souza, D.F. 2012. Effect of creep feeding and creep grazing on the characteristics of Tifton and Italian ryegrass pastures and on sheep performance. Ciência Animal Brasileira 13:165-174

Sousa, J. E. R.; Oliveira, S. M. P.; Lima, F. A. M.; Silva, F. L. R. and Silva, M. A. 2006. Genetic and environmental effects for growth traits in Santa Inês hair sheep at Ceará State, Brazil. Revista Ciência Agronômica 37:364-368.

Souza, D. A.; Selaive-Villarroel, A. B.; Pereira, E. S.; Osório, J. C. S. and Teixeira, A. 2013. Growth performance, feed efficiency and carcass characteristics of lambs produced from Dorper sheep crossed with Santa Inês or Brazilian Somali sheep. Small Ruminant Research 114:51-55. 
Tedeschi, L. O.; Cannas, A. and Fox, D. G. 2010. A nutrition mathematical model to account for dietary supply and requirements of energy and other nutrients for domesticated small ruminants: the development and evaluation of the Small Ruminant Nutrition System. Small Ruminant Research 89:174-184.

Van Emon, M. L.; Schauer, C. S.; Lekatz, L. A.; Eckerman, S. R.; Maddock-Carlin, K. and Vonnahme, K. A. 2014. Supplementing metabolizable protein to ewes during late gestation: I. Effects on ewe performance and offspring performance from birth to weaning. Journal Animal Science 92:339-348.

Vilpoux, O. F.; Yoshihara, P. H. F.; Pistori, H.; Ítavo, L. C. V. and Cereda, M. P. 2013. Sheep confined and fed with diet based on hole cassava as appropriate technology for small producers in Brazil. Revista Brasileira de Gestão e Desenvolvimento Regional 9:211-235. 